\title{
Women and textile manufacture in classical Athens
}

\author{
SARAH MULLER
}

\section{Abstract}

Women in the ancient world are in many respects enigmatic. Ancient literary sources are almost devoid of female voices, and modern archaeologists, until recently, have placed little value on what can be learned from domestic spaces. In the last nine decades however, the study of women in ancient Athens has been a rapidly expanding field of enquiry. In this essay, I discuss textile manufacture in all of its stages and analyse women's involvement in the production of both domestic and commercial textiles. In the ancient world, textiles were extremely valuable, and the spinning and weaving of wool and flax were not only necessary skills for a woman to possess, but also highly respected skills. Modern historians maintain that the textile industry was forced upon citizen women and that it was too closely associated with slave labour to be especially valued. Through an analysis of textile manufacture in classical Athens, along with an examination of the workspaces of women, I argue, rather, that textile manufacture was a valued contribution to the ancient Athenian domestic economy.

\section{Introduction}

First, as we wash wool in a bath to rid the fleece of burrs, so we drive out from the city the parasites and wretched fellows; we card them out and pick them off ... Then we gather the wool together and make a large ball ready for spinning. From this ball, we weave a strong cloak for the state.

(Aristophanes, Lysistrata, 574-586; own translation)

In ancient Athens, women of all classes were responsible for the manufacture of textiles. Spinning and weaving, the methods by which textiles are made, were essential skills. The perceived value of these skills to the domestic economy of classical Athens is difficult to measure as they represented very different things to women of different classes. Slaves were forced to engage in the monotonous and time-consuming labour by their masters, whereas for women of the elite 
weaving was seen as an honourable task. For the 'average' Athenian citizen woman, weaving was simultaneously the mark of a good wife, a religious duty, a domestic responsibility, her traditional role, and, of course, a contribution to the oikos. Some modern historians maintain that the textile industry was forced upon citizen women to keep them secluded in the house and that it was too closely associated with slave labour to be especially valued. ${ }^{1}$ Through an analysis of ancient texts and archaeological evidence I examine this proposition, but my principal argument is that the creation of textiles contributed directly to the Athenian domestic economy.

\section{The value of textiles}

With the coming of the Industrial Revolution, cloth has become cheap and quick to produce and, in the West at least, we give cloth no more thought than a natural material such as wood or stone. In ancient Greece, however, weaving was recognised as particularly important to the economy. In the world of Homer, textiles were extremely valuable items and, like gold, were a measure of wealth: Odysseus in Homer's Odyssey is often given gifts of fine cloaks, alongside other valuable items (Hom. Od. 14.519-567, 19.175-218, 19.240-255). His garments are described as being as fine as an onionskin or otherwise very luxurious (Hom. Od. 19.225-234). The ransom to be paid by Priam for his son Hector included 12 each of robes, cloaks, coverlets, white mantles and tunics (Hom. Il. 29.228-232). In classical Athens, textiles remained valuable items and, as Pomeroy observes, could be used domestically, traded or turned into cash. ${ }^{2}$ Demosthenes lists his mother's apparel as part of his inheritance, along with his father's factories, slaves and gold (Dem. 27.10), and Ischomachus explains that he keeps his most valuable blankets in the secure storeroom of his house (Xen. Oec. 9.3). Ischomachus also informs his wife that 'whenever you take a slave who has no knowledge of spinning, and teach her that skill so you double her value to you' (Xen. Oec. 8.41). This evaluation gives us some evidence of the degree to which textiles in classical Athens were valued. The Gortyn law code of the city of Gortyn in southern Crete stipulates that, because of the inherent value of textiles, upon divorce, women were entitled to a large fraction of the textiles that they had produced. Although it is not known whether a similar provision existed in Athens, it confirms the importance of textiles in the Greek world and suggests that the labour of production was to some extent measurable.

\footnotetext{
Gomme 1925, 1-25; Wright 1923; Pomeroy 1975, 71.

Pomeroy 1994, 62.
} 
Wool and linen were the most commonly used fabrics in ancient Athens. There is also evidence of silk clothing introduced to Athens during the classical Greek period. ${ }^{3}$ Silk was a luxury item. Its production, for the most part, was based in China and India, which produced 'wild silk'. The island of Amorgos in the Aegean Sea was another possible source. ${ }^{4}$ Elizabeth Barber notes that imported silk could be rewoven in Europe. ${ }^{5}$ This would have been quite a difficult task on the traditional Greek warp-weighted loom. ${ }^{6}$ There is no doubt that textile manufacture in general was particularly time-consuming: the process of preparing wool or flax, spinning the fibres and finally weaving the thread, generally on an upright loom, to make cloth could take many weeks, depending on the complexity of the final product.

Textiles were used in great quantities as furnishings, garments and bedding, among other things. They were regularly sold and traded in Athens, as detailed below, and this implies that textiles had an inherent economic value. Importantly, however, they were also impressive symbols of the wealth of a household. In the home, girls learned to work wool and to weave, spending much of their time working on their trousseau. ${ }^{7}$ A woman's trousseau, the garments, soft furnishings and cloths that she produced during childhood, represented her contribution to a marriage. Further, Thucydides lists linen clothing, together with gold brooches, as symbolic of wealthy Athenian citizens who lived a luxurious lifestyle (1.6.3).

Evidence for the wide range of textile items comes predominantly from vase paintings. In The Australian National University (ANU) Classics Museum there are depictions of men's and women's clothing as well as shawls, blankets, seat coverings and bedding (Figure 1; ANU Classics Museum, 65.32, BullHorn Rhyton). Close examination of garments depicted in vase paintings and descriptions of cloth in literary sources make it clear, however, that many of the textiles produced were not simple blankets or plain garments. From Odysseus' robes to the intricate woven designs that are worn by women in vase paintings, the evidence attests to the creativity and skill that was necessary to produce such items.

\footnotetext{
3 Fragments of silk wrappings have been found in a sundried brick tomb in the Athenian Kerameikos. The tomb was erected at the end of the fifth century BCE, and is suspected to be the burial plot of Alcibiades (Knigge 1991, 109-110).

4 Miller 1997, 77-78; Richter 1929, 27-33.

Barber 1991, 32.

For a description of the warp-weighted loom see: Manufacturing textiles.

Demand 1994, 10.
} 


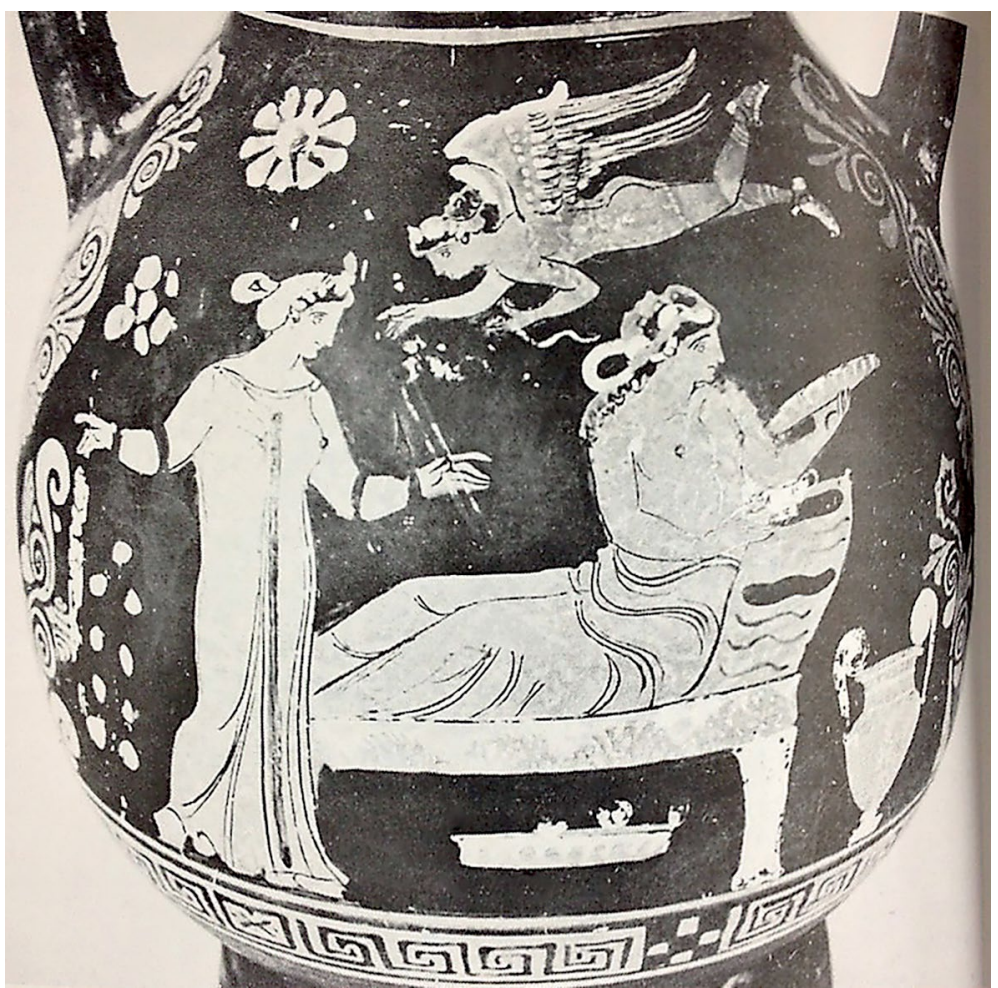

Figure 1. Apulian red-figure pelike, c. 340 BCE.

ANU Classics Museum, 76.13. Note the draping of the garments and the sofa that appears to be upholstered. Photo: Sarah Muller.

\section{Manufacturing textiles}

Prior to the invention of the spinning wheel in medieval Europe, thread was spun on a drop spindle and all cloth woven on handlooms. A drop spindle is composed of a circular clay weight, called a spindle whorl, attached to the bottom of a short wooden rod. The spindle whorl is used to give the spindle momentum as it turns (ANU Classics Museum, 01.05, spindle whorl, 3rd-1st century BCE). When tied to a length of raw wool, the spindle spins quickly and produces a continuous thread. It requires a great deal of practice to create a length of thread that is strong enough and thin enough to be used to weave cloth. In Greece, the most common way to weave was on a warp-weighted loom. This was an upright loom in which the threads were held taut at the bottom by weights (Figure 2). These loom weights appear prolifically at archaeological sites throughout the Mediterranean (ANU Classics Museum, 01.03, seven terracotta loom weights, $3 \mathrm{rd}-2 \mathrm{nd}$ century $\mathrm{BCE}$ ). Indeed, they are so common that, until 
recently, little attention was paid to them. In the excavations of Troy, thousands of loom weights and spindle whorls have been uncovered and are now on display at the Archaeological Museum of Istanbul. ${ }^{8}$

Unfortunately, very little actual cloth has survived from the period. Further, at early excavations throughout the Mediterranean, textile fragments were often discarded as 'rags'. Similarly, many textile tools, like spindles and the looms themselves, which are made of wood, no longer remain. For these reasons, Barber has described researching the work of ancient women as 'finding the invisible'. ${ }^{9}$

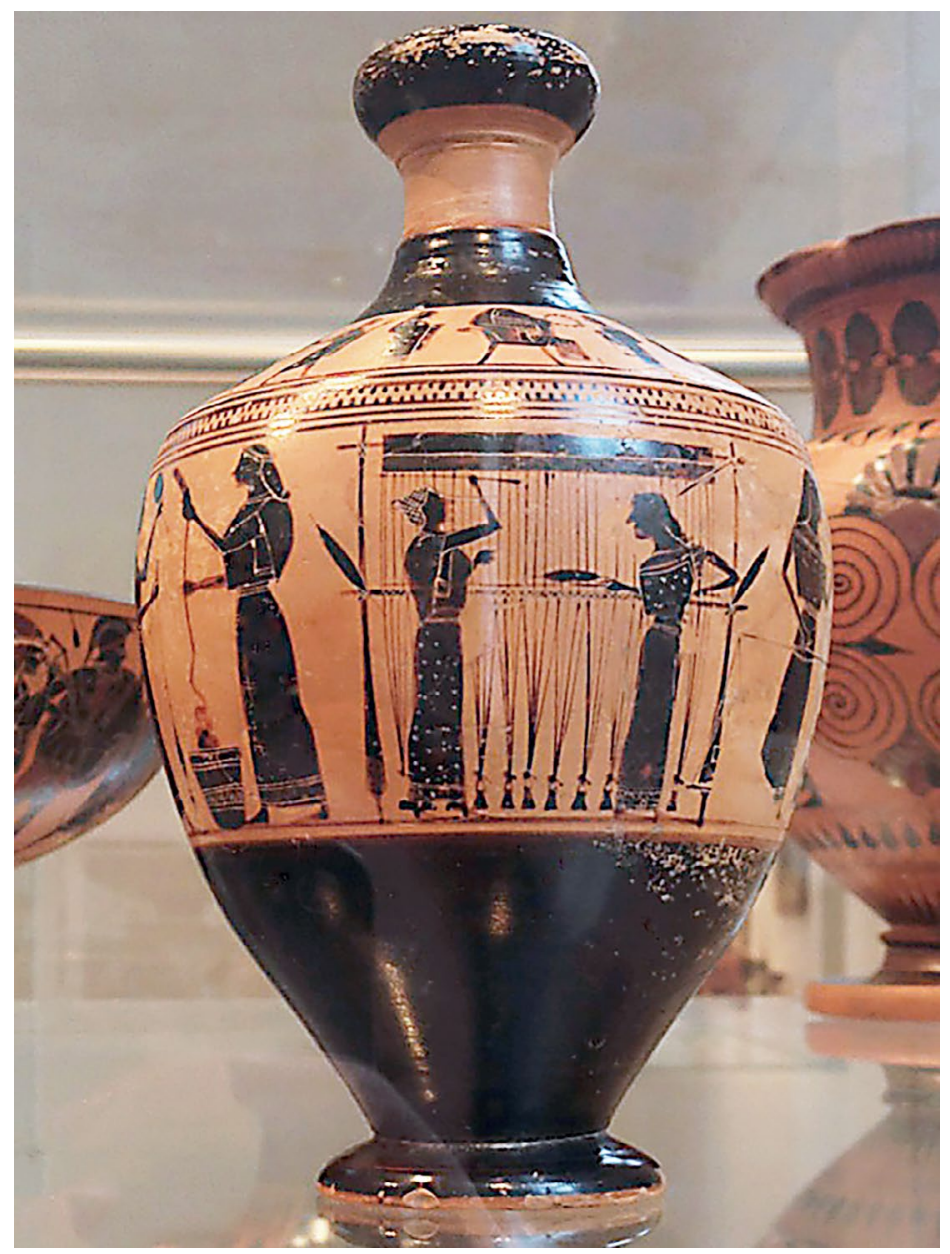

Figure 2. Black-figure terracotta lekythos, attributed to the Amasis Painter, Greek, Attic, c. 550-530 BCE.

New York, Metropolitan Museum, 31.11.10. Photo: Sarah Muller.

8 Edmunds, Nagy and Jones (no date) 7-8.

9 Barber 1995, 286. 
In order to attain a comprehensive and balanced view of the lives of women, it is crucial that many less conventional sources are studied. Archaeologists now recognise the wealth of information that can be gained from examining deposits of artefacts associated with the production of textiles. These sometimes enable them to draw conclusions about where women would have worked in the household and, potentially, how much cloth each household could produce. ${ }^{10}$ As noted above, domestic archaeology is a burgeoning field of study.

\section{The importance of women's roles in the manufacture of textiles for domestic use}

The role of women in textile manufacture dates back to the Neolithic period. This seems to be because women were charged with the care of children and, as a result, tended to work in ways that were compatible with this duty. Dangerous work and tasks that demanded uninterrupted attention were unsuitable for women and tended to be done by men, whereas tasks such as cooking food and spinning and weaving wool were well suited to and compatible with child-rearing. ${ }^{11}$ A blackfigure Attic plaque dated to the sixth century BCE depicts a woman weaving at a horizontal loom while a girl sits and plays behind her (Figure 3).

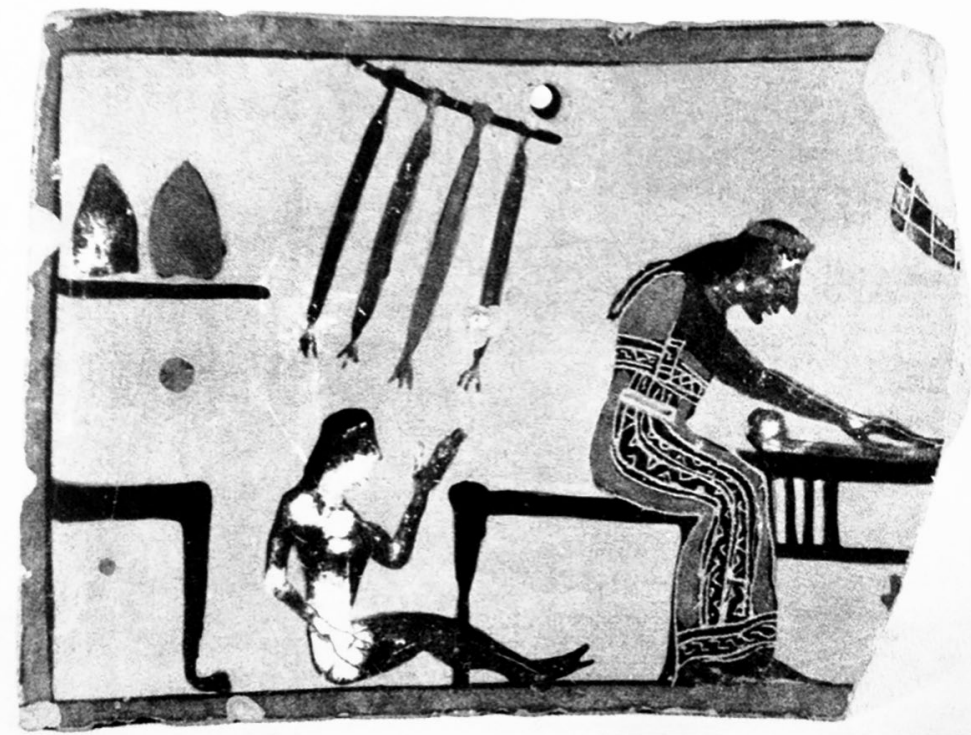

Figure 3. Attic black-figure plaque, c. 560 BCE. Athens, National Archaeological Museum, 2525. Photo: Sarah Muller.

10 Measuring the quantity of domestically produced cloth, however, is notoriously difficult, and, currently, there is limited evidence to support any conclusions.

11 Barber 1995, 29-30. For illustrations of women spinning wool whilst caring for children see Clairmont 
As far back as the Greek Dark Ages (1100-800 BCE), female burials are identified by spindle whorls and the earliest myths indicate that, while men were given ploughs to work the land, women were given looms. ${ }^{12}$

Many classical texts clearly define the creation of domestic textiles as the responsibility of women. In the idealised house of Ischomachus, his wife is responsible for making textiles and supervising the slaves who carry out the weaving (Xen. Oec. 7.20-23; also Men. Sam. 233). The myths of ancient Greece closely link women with weaving: Ariadne gave the thread to Theseus that led him to the centre of the Minoan labyrinth and safely back out again (Hom. Il. 18: 591-592); in Homer, Penelope, wife of the great Odysseus, wove by day and unravelled by night (Hom. Od. 24.125-146); and Helen is similarly preoccupied during the day at her loom (Hom. Il. 3.125-130; also Ovid. Met. 6.1-25). Grave stelai also attest to this female occupation. During the fourth century in particular grave stelai commonly depicted domestic scenes, including women with spindles, baskets of wool, chests or children. It is important to remember that only wealthy Athenians could afford elaborate memorials like these; such images are probably reflections of the upper class. ${ }^{13}$ Nevertheless, they provide further evidence of the link between women and textile manufacture.

There are also examples in the literary record of supposed reversals of traditional gender roles. A prime example of this is Lysistrata, who in Aristophanes' play of the same name, declares:

Girdled now sit humbly at home,

Munching beans, while you card wool and comb.

For war from now on is the Women's affair. ${ }^{14}$

Lysistrata later specifically uses the metaphor of wool working to explain the way in which Athens can stop the civil strife it was experiencing by expelling the troublemakers: she likens the warmongers to burrs that must be picked out of the wool before it can be spun into a cohesive thread, or a cohesive society (Ar. Lys. 568-613).

The motivations behind Aristophanes' work are challenging to reconcile. Although he portrays his protagonist Lysistrata as a powerful and commanding woman, he does so in the context of a comedy in which conventions are often overturned for comic value. He also portrays the forceful heroine as childless and masculine. In this way, Aristophanes is able to emphasise the brilliance and potential of Lysistrata, far removed from the constraints placed on ordinary women. By creating an overtly masculine heroine he in fact works to reinforce 
gender stereotypes rather than present a plausible scenario of powerful female leaders. Aristophanes' resounding message is that the place of women is in the home attending to household tasks.

A man in classical Athens, unless he was a slave or metic, would not normally be expected to perform a woman's task. Thus, in Aristophanes' Birds, Cleisthenes is portrayed as particularly effeminate when he is depicted weaving like a woman instead of bearing arms (Ar. Birds, 829-31). Xenophon, in a discussion on the roles of the sexes, writes that the gods made men more suited to outdoor tasks and women more adapted to indoors (Xen. Oec. 7.23). He went further to argue, 'each member of the pair is the more useful to the other, the one being competent where the other is deficient' (Xen. Oec. 7.23). This is an echo of Homer's lines '[b]y how much men are expert of propelling a swift ship on the sea, by this much are women skilled at the looms' (Hom. Od. 7.108-111). It is important to remember, however, that this binary male/female divide may not necessarily have represented reality: we should recall the case of Demosthenes, who makes and sells ribbons with his mother (Dem. 57.31). Nevertheless, the traditional demarcation of the roles of men and women attests neither to the servitude nor the liberty of women, merely that each has their separate responsibilities, and that both contribute to the functioning of the community.

\section{Weaving: An honourable skill}

Weaving was not only a necessary duty of Athenian women, it was also an honoured skill that was held in high esteem. ${ }^{15}$ Skill at wool working was an important and desirable quality to look for in a wife no matter what class she belonged to: Ischomachus explains that he provides shelter for his wife so that she may undertake 'the rearing of infant children ... making food out of the harvest [and] ... the making of clothing from wool' (Xen. Oec. 7.10-21). In the epic tradition, all classes of women are represented spinning and weaving wool: Helen in the Odyssey is given a golden distaff on which to spin wool (Hom. Od. 4.130), and in the Iliad Penelope weaves upon the loom described at line 2.94; also in the Iliad, a poignant simile describes a hard-working woman who weighs and spins wool in order to support her family (Hom. Il. 12.432435). It was a common domestic occupation that was universally practiced: even into Roman times, spinning and weaving by women at home remained a symbol

15 Hooper 1947, 18 
of traditional mores. ${ }^{16}$ Clearly, textile manufacture was strongly linked with the virtue and dignity of the mature citizen woman, who thereby embodied stability and cohesion. ${ }^{17}$

On inscriptions found in Athens there are lists of women who were manumitted in the city between 349-320 BCE. In these lists there is a predominance of wool workers. This attests to textile manufacture as being an important undertaking not only for citizen women but also for slaves. ${ }^{18}$ Because of this, social historians such as Pomeroy have argued that, although women's work was necessary to the functioning of society, it was too closely associated with the monotonous and laborious work of slaves to be especially honourable. ${ }^{19}$ The work of men, on the other hand, included tilling the fields and sowing and harvesting crops - work which was also undertaken by slaves and which seems itself dull and demanding. This work, although equally as important to the Athenian household as was the production of clothing and bedding, seems not to hold the same stigma.

Wool working was not restricted to citizen women, freedwomen and slaves, but was also undertaken by highborn women. Each year in Athens two young women were responsible for the creation of a woollen garment for the statue of Athena that stood on the Acropolis. This was part of a major religious ceremony, the procession of the Panathenaea, which honoured Athena, the patron goddess of Athens and the patroness of weaving. The privileged women were chosen from among the elite class to weave the garment over a period of nine months. ${ }^{20}$ Their involvement in the religious procession demonstrates that women had a firm place in public worship. Of course, this was not the only involvement women had in religious affairs. In Aristophanes' Lysistrata we learn details of a number of cult celebrations conducted by women, such as that in honour of Adonis, as well as other more solemn acts of worship (636-647). Women in myth were also associated with weaving, the most notable being Helen, Penelope and Andromache. This strong connection between myth, religion and the craft of wool working show that spinning and weaving were familiar, essential activities, conspicuously associated with women and respectability.

\footnotetext{
16 Hooper 1947, 20.

17 Sheramy Bundrick (2008, 283-334) examines the prominence of domestic imagery on vase paintings during the sixth and fifth centuries BCE. During this period, particularly from the Battle of Salamis (480 BCE) to the end of the Peloponnesian War (404 BCE), the social and political climate in Athens was tumultuous and the city was in a near-constant state of war. Bundrick argues that, in response to this turmoil, there is a clear trend to promote an ostensible appearance of peace and stability, in particular, a stable and harmonious oikos, and that images of women in domestic settings on vase paintings increased significantly. Such scenes included marriages, women spinning and weaving, and women in the household. This is an interesting idea and suggests that, for the ancient Athenians, images of women in such a domestic setting, in particular women weaving, reassured the population of the preservation of peace at home and was something of a psychological comfort. I argue, however, that there is not yet enough evidence to confirm this assertion.

18 Tod 1946, vol. 2, 1553-78.cf.m.

19 Pomeroy 1975, 71.

20 Barber 1995, 151.
} 


\section{Weaving workspaces}

In order to gain a deeper understanding of the freedoms afforded to women, there has been much recent interest in the analysis of the physical space in which women lived their lives. Several influential, though somewhat controversial, studies have examined whether the household was divided along gender lines and, if so, how. Susan Walker and Penelope Allison have undertaken important studies in this area. ${ }^{21}$ They point to archaeological deposits of objects associated with women, such as loom weights and spindle whorls, in order to interpret the spaces occupied by their users. Walker, through her examination of vase paintings in which men and women are respectively associated with typically masculine objects and typically feminine objects, argues that, 'we are seeing the work of vase painters who were raised in a society and were working for a clientele that thought of space as gendered'.$^{22}$ But it is important to remember that spinning and weaving were tasks that could be easily moved at will. Pomeroy, Walker and Allison, among other social historians, have all advised caution when attempting to understand the use of space in the ancient world. Allison, with respect to the Roman world, warns that 'behaviour was more important than fixed architectural elements', meaning that although we may find loom weights in a particular room of the house, there is no reason why such looms could not have been used in any other area such as the courtyard or the hallways. ${ }^{23}$ As the work of women would have required good light, we come across vase paintings that regularly depict women working between columns, indicating they were in the courtyard of the house. ${ }^{24}$

Archaeology indicates that the household, as we have seen above, rather than being a place of isolation was in fact a backdrop for social integration. We can see that men and women from different classes would meet in the oikos and that the evidence to support exclusively female and male spaces in Athenian households is tenuous.

\section{Selling the surplus}

In order to achieve self-sufficiency in textile production, landed Athenians reared sheep and goats for their own wool stocks. Hodkinson writes that wealthy farmers who were able to maintain 50 to 70 sheep could make significant

21 Allison 1999; Walker 1993.

22 Walker 1993, 151. Most vases would have been commissioned by wealthy Athenians; 'art for art's sake' was an idea of nineteenth-century Romantics.

23 Allison 1999, 151.

24 'Attic red-figured kylix', attributed to the Oedipus painter, c. 470 BCE. 
profits from the sale of wool. ${ }^{25}$ However, not every family kept their own animals nor were the womenfolk in every family solely engaged in weaving for private consumption. This is why in the primary sources we see examples of wool salesmen who sold their goods to those who had no access to their own sheep, such as in Aristophanes' comedy Frogs. In the marketplace, the character Dionysus remarks that wool merchants regularly wet their wool to make it heavier in order to get a higher price: 'like fabric salesmen he made his verse wet just like the wool' (Ar. Frogs, 1386).

Although the majority of textiles would have been produced for domestic use, there are examples of women in fifth and fourth-century BCE Athens selling what they had made. Most likely this was excess that had been produced and was surplus to domestic requirements. We find an example of women working wool in order to earn money in Demosthenes' law court speech Against Euboulides, in which the speaker defends his mother who sells ribbons in the marketplace (Dem. 30-36). Just how these ribbons were manufactured is unclear but we can assume that some form of wool working was necessary to produce them. The speaker also makes it clear that if their household had been wealthy, his mother would have had no need to sell ribbons, but, as they were poor, they required the extra income. ${ }^{26}$ Although the prospect of women working in the agora was not considered the ideal in ancient Athens, it seems as though it was nevertheless a common occurrence. ${ }^{27}$

In Xenophon's Memorabilia, Socrates attempts to remedy the disparaging way in which female producers and vendors are viewed. The highborn Aristarchus complains that due to the political strife in Athens his house was crowded with female relatives who were seeking safety (Xen. Mem. 2.7.2). The women had no means by which to support themselves and Aristarchus was struggling to keep them. To remedy this, his friend Socrates advised that he should put them to work making clothes and sell what they produce. Socrates explains that this is a suitable occupation even for the highborn women among them

\footnotetext{
25 Hodkinson 1988, 64.

26 See also Ar. Frogs, 1346-51.

27 Elsewhere in the Greek world, Leonidas of Taras, admittedly outside the time and space with which we are concerned, describes the life of an 80-year-old spinning woman: 'Often had she thrust sleep away from her, morning and evening, to ward off poverty. She used to sing to her spindle and help-mate distaff, and by the loom until the dawn she spun with the Graces that long task of Athene, or with wrinkled hand on wrinkled knee smoothed thread sufficient for the loom, a lovely woman. At eighty years, beautiful Platthis, who wove so beautifully, beheld the waters of Acheron' (Leonidas of Tarentum, AP. 72. 7.726). This epitaph implies that the woman, although pitied in death, was not pitied for her work. Barbara Hughes Fowler writes: '[i]t is comforting to know that not all women, not even those who had to work for their living, were considered grotesques' (Fowler 1989, 100).
} 
(Xen. Mem. 2.7.12). The views of Demosthenes and Aristophanes demonstrate that women, if need be, sold the goods of their labour. In general, however, and despite Socrates' assertion, retail trade was not a highly respected profession. ${ }^{28}$

\section{Conclusion}

Studies of ancient Athenian women have too often focused on their lack of economic freedoms rather than their contributions to the economy. I argue that if work is valued, then workers are valued, and in fifth-century BCE Athens, thread and cloth mattered. Representations of women spinning and weaving abounded within this period, which indicate that the work of women was a valued asset to society. Women who could weave were more desirable and well-respected. For ancient Athenians, spinning and weaving was a necessity; it was also a metaphor for human skill, honour, cohesion and life. To confirm the importance of thread work, it commonly appeared in mythology and is strongly tied with the most important goddess of ancient Athens: Athena. Textile manufacture was central to the ancient Athenian domestic economy and the role of women in the Athenian textile industry was significant.

\section{Bibliography}

\section{Ancient sources}

Aristophanes. Lysistrata. Translated by A. Sommerstein. Boston: Addison Wesley Publishing, 2003.

—. Birds. Translated by E. O'Neill. New York: Random House, 1938.

—. Frogs. Translated by M. Dillon. Massachusetts: Tufts University, 1995.

Demosthenes. 27: Against Aphobus 1. Translated by A. T. Murray. London: William Heinemann Ltd, 1939.

- 57: Against Euboulides. Translated by A. T. Murray. London: W. Heinemann Ltd, 1939.

Homer. Iliad. Translated by R. Lattimore. Chicago: University of Chicago Press, 1961.

Odyssey. Translated by R. Lattimore. Sydney: Harper Collins Publishers, 2007.

28 Austin and Vidal-Naquet 1972, 13. 
Menander. The Girl from Samos. Translated by N. Miller. London: Penguin Books, 1987.

Ovid. Metamorphoses. Translated by B. More. Boston: Cornhill Publishing Co., 1922.

Thucydides. The History of the Peloponnesian War. Translated by M. Finley. London: Penguin Books, 1954.

Xenophon. Memorabilia. Translated by J. R. Smith. Boston: Ginn and Company, 1998.

- Oikonomikos of Xenophon. Translated by C. Brownson. London: Harvard University Press.

\section{Modern sources}

Allison, P. 1999. Archaeology of Household Activities. London: Routledge.

Austin, M.M. and Vidal-Naquet, P. 1972. Economic and Social History of Ancient Greece. London: Batsford.

Barber, E. 1991. Prehistoric Textiles. Princeton: Princeton University Press.

— 1995. Women's Work: The First 20,000 Years. New York: W. W. Norton \& Company.

Bundrick, S. 2008. 'The Fabric of the City: Imaging Textile Production in Classical Athens.' Hesperia 77:283-334.

Clairmont, C. 1993. Classical Attic Tombstones. Switzerland: Akanthus.

Demand, N. 1994. Birth, Death, and Motherhood in Classical Greece. Baltimore: Johns Hopkins University Press.

Edmunds, S., Nagy, N. and Jones, P. (no date). Text \& Textile: An Introduction to Wool-Working for Readers of Greek and Latin. Washington: Center for Hellenic Studies.

Fowler, B. 1989. The Hellenistic Aesthetic. Wisconsin: University of Wisconsin Press.

Gomme, A.W. 1925. 'The Position of Women in Athens in the Fifth and Fourth Centuries.' Classical Philology 20:1-25.

Hodkinson, S. 1988. 'Animal Husbandry in the Greek Polis.' In Pastoral Economies in Classical Antiquity, edited by C. R. Whittaker, 35-86. Cambridge: The Cambridge Philological Society. 
Hooper, L. 1947. Hand-loom weaving: plain and ornamental. London: Pitman House.

Knigge, U. 1991. The Athenian Kerameikos. Athens: Krene Editions.

Miller, M. 1997. Athens and Persia in the Fifth Century BC: A Study in Cultural Receptivity. Cambridge: Cambridge University Press.

Osborne, R. 2011. The History Written on the Classical Greek Body. Cambridge: Cambridge University Press.

Pomeroy, S. 1975. Goddesses, Whores, Wives and Slaves: Women in Classical Antiquity. New York: Schocken Books.

_. 1994. Xenophon Oikonomicus. Oxford: Clarendon Press.

Richter, G. 1929. 'Silk in Greece.' American Journal of Archaeology 33:27-33.

Tod, M.N. 1946. Greek Historical Inscriptions Vol. 2: 403BC to 323BC. Oxford: Clarendon Press.

Vetter, L. 2005. Women's Work as Political Art: Weaving and Dialectical Politics in Homer, Aristophanes and Plato. Maryland: Lexington Books.

Walker, S. 1993. 'Women and Housing in Classical Greece.' In Images of Women in Antiquity, edited by A. Kuhrt \& A. Cameron, 81-91. London: Routledge.

Wright, F. 1923. Feminism in Greek Literature. New York: E.P. Dutton \& Co. 
This text is taken from The ANU Undergraduate Research Journal, Volume Six, 2014, edited by Jonathon Zapasnik and Alexandra Hogan, published 2015 by ANU eView, The Australian National University, Canberra, Australia. 